\title{
PIN2/TERF1-Interacting Telomerase Inhibitor 1
}

National Cancer Institute

\section{Source}

National Cancer Institute. PIN2/TERF1-Interacting Telomerase Inhibitor 1. NCI

Thesaurus. Code 197216.

PIN2/TERF1-interacting telomerase inhibitor 1 (328 aa, $37 \mathrm{kDa}$ ) is encoded by the human PINX1 gene. This protein plays a role in both microtubule binding and the inhibition of telomerase. 